\title{
Interactions of Influenza Virus with Cultured Cells: Detailed Kinetic Modeling of Binding and Endocytosis ${ }^{\dagger}$
}

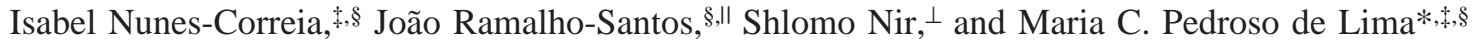 \\ Department of Biochemistry, University of Coimbra, Apartado 3126, 3000 Coimbra, Portugal, Department of Zoology, \\ University of Coimbra, 3000 Coimbra, Portugal, Oregon Regional Primate Research Center, Beaverton, Oregon 97006, \\ Seagram Center for Soil and Water Sciences, Faculty of Agricultural, Food and Environmental Quality Sciences, \\ Hebrew University of Jerusalem, Rehovot 76100, Israel, and Center for Neuroscience and Cell Biology of Coimbra, \\ University of Coimbra, 3000 Coimbra, Portugal
}

Received May 27, 1998; Revised Manuscript Received October 14, 1998

\begin{abstract}
We performed a detailed kinetic analysis of the uptake of influenza virus (A/PR8/34) by Madin Darby canine kidney (MDCK) cells in culture. Experimental procedures were based on the relief of fluorescence self-quenching of the fluorescent probe octadecylrhodamine B chloride (R18) incorporated in the viral envelope. Equilibrium for binding of influenza virus to MDCK cells $\left(2.5 \times 10^{6} / \mathrm{mL}\right)$ was reached quicker with temperature increases due to a faster dynamic mobility of the particles. We deduced that there are two kinds of binding sites for influenza virus in MDCK cells and determined the kinetic parameters of the binding process (adhesion and detachment rate constants), using a mass action kinetic model. As the temperature increases, the number of binding sites for influenza virus decreases, especially the high-affinity binding sites, whereas the value of the affinity constant for virus binding to the binding site, $k$, increases. Nevertheless, the binding association constant at equilibrium $K_{i}$, which is given by $K_{i}$ $=N_{i} k_{i}$, where $N_{i}$ is the number of binding sites per cell, declines as the temperature increases. When endocytosis occurs, the total uptake of virions by the cells is larger than that observed in the process of binding at the same temperature, and the uptake proceeds for longer times. Using our mass kinetic model, we determined that at $20^{\circ} \mathrm{C}$, the rate constant of endocytosis, $\epsilon$, for influenza virus with this cell line is $2.6 \times 10^{-4} \mathrm{~s}^{-1}$, i.e., in the same range as in studies on endocytosis of liposomes.
\end{abstract}

Influenza virus is a lipid-enveloped virus that belongs to the family of orthomyxoviruses. Imperative for infection and survival of the virus is the ability to introduce its nucleocapsid, which contains the genetic information, into the cytoplasm of the host cell for replication. Infection of animal cells by influenza virus begins with the interaction of virus particles with cell surface sialic acid residues $(1-3)$ as mediated by hemagglutinin (HA), a viral membrane glycoprotein (4-6). After virus - cell binding, virions are internalized by receptor-mediated endocytosis. This complex event is normally triggered when clathrin is recruited to the plasma membrane by specific adaptors, thus forming clathrin-coated pits where virus-receptor complexes will accumulate. These pits will eventually pinch off into the cell cytoplasm, forming virus-containing clathrin-coated vesicles. Following internalization, vesicles are quickly uncoated and fuse with

$\dagger$ This work was supported by Grant PRAXIS XXI/BM/186/94 from JNICT, Portugal (I.N.-C.), by a PRAXIS XXI postdoctoral fellowship, FCT, Portugal (J.R.-S.), by Fundação Luso-Americana para o Desenvolvimento, FLAD, Portugal (J.R.-S.), by European Union Grant BIO4CT97-2191 (M.C.P.d.L.), and by Grant PRAXIS/PCNA/P/BIO/45/96 from JNICT, Portugal (M.C.P.d.L.).

* To whom correspondence should be addressed. Fax: 351-39853607. E-mail: mdelima@cygnus.ci.uc.pt.

Department of Biochemistry, University of Coimbra.

$\S$ Center for Neuroscience and Cell Biology of Coimbra, University of Coimbra.

"Department of Zoology, University of Coimbra and Oregon Regional Primate Research Center.

${ }^{\perp}$ Hebrew University of Jerusalem. endosomes, although the specific mechanism for this event remains obscure (7). Virions are therefore delivered into endosomes, compartments involved in intracellular sorting (7). The acidic $\mathrm{pH}$ generated in these organelles by the vacuolar proton ATPase induces a conformational change in the viral hemagglutinin, which triggers fusion between the viral envelope and the endosomal membranes $(4,8,9)$.

The adhesion of vesicles and virions to cells, and the subsequent fusion between membranes, have been studied extensively from a large number of perspectives (10-15). Although many biochemical aspects related to this process have been elucidated, detailed quantification of viral entry has been lacking. Recent work has involved a kinetic analysis, aimed at obtaining the rate constants for the adhesion and/or fusion steps $(3,16-24)$. Quantitative studies may provide a better understanding of all steps involved in virus replication, which may be very useful, for example, in optimizing vaccines and recombinant protein production. Experimental results obtained with these systems may also be helpful in developing strategies for gene therapy (relying on the uptake of carriers such as liposomes by cells) and in designing infection regimens for viral expression.

We have developed a mass action kinetic model that provides the possibility of "uncoupling" the kinetics of binding and fusion. The procedure has yielded the values for the rate constants of the aggregation and fusion processes, during virus - cell interaction, thus enabling Nir et al. to obtain a more detailed description and prediction of the 
kinetics of the overall fusion process $(21)$. This model has also been employed to evaluate the kinetics of fusion between influenza virus and liposomes (23), of Sendai virus fusion with phospholipid vesicles, erythrocyte ghosts, and cells (11, $21,22)$, and of influenza virus fusion with cells lacking an endocytic capacity $(3,18)$. By employing a similar formalism, we provided equations for uptake of particles (liposomes) by cells via endocytosis $(20,24)$.

In this study, we present a kinetic analysis of binding and endocytosis of influenza virus (A/PR8/34) with Madin Darby canine kidney $(\mathrm{MDCK})^{1}$ cells in culture. These are known to exhibit endocytic capacity, being infected by influenza virus following its internalization by endocytosis (25). Such a study may facilitate the efforts to more accurately define the distinct steps involved in the process of influenza virus infection. All experimental procedures are based on the relief of fluorescence self-quenching of the fluorescent probe octadecylrhodamine B chloride (R18) incorporated in the viral membrane. We have obtained the separate rate constants for virus attachment to the plasma membrane of the cell, for its detachment, and for virus endocytosis.

\section{MATERIALS AND METHODS}

Materials. Influenza virus A/PR8/34 (H1N1) strain was obtained from SPAFAS (Preston, CT). The virus was grown for $48 \mathrm{~h}$ at $37^{\circ} \mathrm{C}$ in the allantoic cavity of 11-day-old specific pathogen-free embryonated eggs, purified by discontinuous sucrose density gradient centrifugation, and stored at -70 ${ }^{\circ} \mathrm{C}$ in phosphate saline buffer. Cells were obtained from the University of California at San Francisco Cell Culture Facility (San Francisco, CA). Antimycin A, $\mathrm{NaN}_{3}$, and Sephadex G-25 were purchased from Sigma (St. Louis, MO). Octadecylrhodamine B chloride (R18) was obtained from Molecular Probes (Eugene, OR).

Cells. MDCK cells were maintained in DME medium containing $10 \mathrm{mM}$ Hepes and $1 \mathrm{~g} / \mathrm{L}$ sodium bicarbonate, supplemented with $10 \%$ fetal bovine serum $(\mathrm{pH} 7.4)$. The cells were grown in T-75 flasks under a $5 \% \mathrm{CO}_{2} / 95 \%$ air atmosphere at $37^{\circ} \mathrm{C}$ up to cell confluence. As this cell line grows adherent to the bottom of the flasks, just before experiments, cells were placed in suspension after treatment for $10 \mathrm{~min}$ with a dissociation buffer (enzyme-free). The cells were harvested and washed by centrifugation at $180 \mathrm{~g}$ for 5 min at room temperature in DME medium and then once in medium A containing $110 \mathrm{mM} \mathrm{NaCl}, 5 \mathrm{mM} \mathrm{KCl}, 2 \mathrm{mM}$ $\mathrm{CaCl}_{2}, 1 \mathrm{mM} \mathrm{MgCl} 2,10 \mathrm{mM}$ glucose, $10 \mathrm{mM}$ Hepes, 10 $\mathrm{mM}$ Mes, and $10 \mathrm{mM}$ sodium acetate ( $\mathrm{pH}$ 7.4). The cells were resuspended in the latter buffer and kept on ice in polypropylene tubes until they were used. Cell viability was determined by Trypan blue exclusion and was routinely above $95 \%$.

Viral Labeling. Viral preparations were labeled with the fluorescent probe octadecylrhodamine B chloride as previously described $(13,26)$. The final self-quenching concentration of added probe corresponded to approximately $5 \mathrm{~mol}$ $\%$ of the total viral lipid, and that of ethanol was less than $1 \%(\mathrm{v} / \mathrm{v})$. The mixture was incubated in the dark for 30-45 min at room temperature. R18-labeled virus was separated

\footnotetext{
${ }^{1}$ Abbreviations: R18, octadecylrhodamine B chloride; MDCK cells, Madin Darby canine kidney cells.
}

from noninserted fluorophore by passage through a column (Bio-Rad bio-spin) of Sephadex G-25 and was collected by centrifugation at $850 \mathrm{~g}$ for $4 \mathrm{~min}$. The protein concentration of the labeled virus was determined by the Sedmak assay (27).

Binding and Cell Association. Fluorescently labeled influenza virus was incubated with MDCK cells $\left(5.0 \times 10^{6}\right.$ cells), in a final volume of $2 \mathrm{~mL}$ of medium A for various times at 4,20 , and $37^{\circ} \mathrm{C}$ for binding experiments and at 20 and $37^{\circ} \mathrm{C}$ for cell association experiments. In the binding experiments performed at 20 and $37^{\circ} \mathrm{C}$, the cells were preincubated for $30 \mathrm{~min}$ at $37{ }^{\circ} \mathrm{C}$ with the following metabolic inhibitors: $1 \mu \mathrm{g} / \mathrm{mL}$ antimycin A, $10 \mathrm{mM} \mathrm{NaF}$, and $0.1 \%$ sodium azide (20). Antimycin A was solubilized in ethanol and was added to the cells to a final ethanol concentration of $\leq 1 \%(\mathrm{v} / \mathrm{v})$. In these cases, the experiments were carried out in the presence of the same endocytosis inhibitors. The cells were sedimented by centrifugation at 4 ${ }^{\circ} \mathrm{C}$ for $8 \mathrm{~min}$ at $180 \mathrm{~g}$, and the fluorescence was measured at $37^{\circ} \mathrm{C}$ in the supernatant and in the pellet following detergent lysis of the virus and the membranes after each experiment with Triton X-100, at a final concentration of $1 \%(\mathrm{v} / \mathrm{v})$. Percentages of binding and cell association were calculated according to the following equation:

$\%$ binding or cell association $=\frac{F_{\text {pellet }}}{F_{\text {supernatant }}+F_{\text {pellet }}} \times 100$

where $F$ is the value of fluorescence. Fluorescence measurements were performed in a Spex Fluorolog 2 fluorometer using the front-face configuration in the emission channel, with excitation at $560 \mathrm{~nm}$ and emission at $590 \mathrm{~nm}$, using 1 and $2 \mathrm{~mm}$ slits in both monochromators. A high-pass filter (50\% transmission at $590 \mathrm{~nm}$; Schott Glass OG590, MellesGriot) was placed between the cuvette and the emission monochromator. The sample chamber was equipped with a magnetic stirring device, and the temperature was controlled with a thermostated circulating water bath.

Kinetic Analysis. We followed the procedure described by Nir et al. (24) with some extension for treating endocytosis.

(a) Equations for Competing Binding of Particles to Several Types of Cells or Receptors: No Endocytosis. Let the molar concentration of cells of type $i(i=1, \ldots, n)$ be $G_{0 i}$. The molar concentration of total and free virus particles will be denoted by $L_{0}$ and $L(t)$, respectively, where $t$ is the time of incubation. Initially, when $t=0, L(t)=L_{0}$. The molar concentration of cells of type $i$ with $I$ surface-bound particles is denoted $A_{i}(I)$. Mass conservation of virus particles is expressed as

$$
L_{0}=L+\sum_{i=1}^{n} \sum_{I=1}^{N} A_{i}(I) I
$$

in which $N_{i}$ is the largest number of particles that can bind to a cell of type $i$. Mass conservation equations for the cells are as follows

$$
G_{0 i}=\sum_{I=0}^{N_{i}} A_{i}(I)
$$

The binding of particles to each cell type is described by 
two parameters: $C_{i}\left(\mathrm{M}^{-1} \mathrm{~s}^{-1}\right)$, the rate constant of association or adhesion, and $D_{i}\left(\mathrm{~s}^{-1}\right)$, the dissociation rate constant. The kinetics of adhesion are described by the equations

$$
\begin{gathered}
\mathrm{d} A_{i}(I) / \mathrm{d} t=C_{i} L A_{i}(I-1)\left(N_{i}+1-I\right) / N_{i}+ \\
D_{i} A_{i}(I+1)(I+1)-C_{i} L A_{i}(I)\left(N_{i}-I\right) / N_{i}-D_{i} A_{i}(I) I \\
\mathrm{~d} L / \mathrm{d} t=-L \sum_{i=1} C_{i} \sum_{I=0} A_{i}(I)\left(N_{i}-I\right) / N_{i}+\sum_{i=1} D_{i} \sum_{I=1} A_{i}(I) I
\end{gathered}
$$

The solution of these nonlinear differential equations is based on Taylor series expansion. A (Fortran) program has been written for the case of binding to $n=2$, but the extension to any order is straightforward.

The application to the case of binding to $n$ types of independent receptors on the same cell requires that $G_{0 i}$ equal $G_{0}$.

For shortcuts in calculations, eqs $1-4$ are equivalent to a bimolecular reaction with the following substitutions:

$$
R_{0}=G_{0} N
$$

and

$$
C=c N
$$

in which $R_{0}$ is the total molar concentration of receptor sites available for the binding of a particle, e.g., a virus, and $c$ is the rate constant for association between a virus particle and a hypothetical cell that includes a single binding site. We have utilized this simplification in solving the equations for binding to several types of receptors.

At equilibrium, eqs $1-6$ yield

$$
r=\left(L_{0}-L\right) / G_{0}=K L /(1+K L / N)
$$

where $r$ is the number of virus particles bound per cell. This equation may be rearranged to a form of a Scatchard plot

$$
r / L=K-r K / N
$$

whose intercept and slope are $K$ and $-K / N$, respectively, or

$$
r / L=k N-r k
$$

where $k N=K, k=c / D$, and $K=C / D$.

In practice, Scatchard plots are drawn by implicitly assuming binding to a single type of receptor, whereas more types of receptors may exist.

We used an initial guess by splitting the Scatchard plots into two linear segments. This provided initial values for $k_{1}$, $N_{1}, k_{2}$, and $N_{2}$. Then refinements were obtained by choosing the best fits. For small virus concentrations, the important parameters were $k_{1}$ and $N_{1}$, which pertain to the high-affinity sites. Their values were close to the initial guess obtained from the linear segment of Scatchard plots corresponding to lower $r$ values.

The initial time points of the kinetics of binding provided the values of $C$. At this stage, the results are less sensitive to $D$ values, since the fraction bound is relatively small. The parameters $D_{1}$ and $D_{2}$ were already fixed by

$$
D_{1}=C_{1} / K_{1} \text { and } D_{2}=C_{2} / K_{2}
$$

The procedure described above applies to virus binding to cells at $4{ }^{\circ} \mathrm{C}$, or at higher temperatures in the presence of inhibitors of endocytosis.

(b) Binding and Endocytosis. In the presence of two types of binding sites, the simplified equations employ the relation

$$
R_{0 i}=G_{0} N_{i}
$$

Let $E$ denote the molar concentration of endocytosed virus, and let $\epsilon_{i}$ denote the rate constants of endocytosis for virus particles bound to receptor sites of type $i$, whose concentrations are $R_{0 i}-R_{i}$, where $R_{i}$ is the concentration of free receptors of type $i$.

$$
\begin{aligned}
& \mathrm{d} L / \mathrm{d} t= \\
& -C_{1} L R_{1}-C_{2} L R_{2}+D_{1}\left(R_{01}-R_{1}\right)+D_{2}\left(R_{02}-R_{2}\right) \\
& \quad \mathrm{d} E / \mathrm{d} t=\epsilon_{1}\left(R_{01}-R_{1}\right)+\epsilon_{2}\left(R_{02}-R_{2}\right) \\
& \mathrm{d} R_{1} / \mathrm{d} t=-C_{1} L R_{1}+D_{1}\left(R_{01}-R_{1}\right)+\epsilon_{1}\left(R_{01}-R_{1}\right) \\
& \mathrm{d} R_{2} / \mathrm{d} t=-C_{2} L R_{2}+D_{2}\left(R_{02}-R_{2}\right)+\epsilon_{2}\left(R_{02}-R_{2}\right)
\end{aligned}
$$

The mass conservation equation for virus particles is

$$
\left(R_{01}-R_{1}\right)+\left(R_{02}-R_{2}\right)+E+L=L_{0}
$$

When $t=0, L(0)=L_{0}, R_{i}(0)=R_{0 i}$, and $E(0)=0$. Hence, the first derivatives $\mathrm{d} L / \mathrm{d} t, \mathrm{~d} R_{i} / \mathrm{d} t$, and $\mathrm{d} E / \mathrm{d} t$ in eqs $12-15$ are known. We take second and third derivatives of these equations and proceed with a Taylor expansion.

To minimize the employment of parameters, we considered in the calculations

$$
\epsilon_{1}=\epsilon_{2}=\epsilon
$$

In addition to eqs $12-16$, we also employed an approximation where only one type of "effective" receptor site was considered, in which case eqs $12-15$ were reduced to those described by Nir et al. (24). This possibility arose since at least for smaller values of $L_{0}$, total viral concentration, most of the contribution to binding and endocytosis came from the high-affinity sites. Thus, we defined a quantity $N_{\text {eff }}$ as being the number of effective binding sites, whose application could simulate virus binding employing the parameters $C$ and $D$ corresponding to the high-affinity binding sites.

\section{RESULTS}

We have used the R18 fluorescence dequenching assay to determine the percentage of influenza virus bound to and associated with MDCK cells. Binding and cell association were quantified by measuring the fluorescence in the supernatant and in the pellet following detergent lysis of the virus and the membranes after each experiment, as described in Materials and Methods. Table 1 shows the time at which equilibrium of binding was reached at various temperatures. Experiments carried out at 20 and $37{ }^{\circ} \mathrm{C}$ were performed in the presence of inhibitors of endocytosis. As the temperature increases, equilibrium of binding was reached quicker due to a faster dynamic mobility of the particles. We have evidence, from previous work performed with influenza virus labeled with R18 and using liposomes and several types of cell lines as target membranes (results not published), that unspecific probe transfer of $\mathrm{R} 18$ at neutral $\mathrm{pH}$ does not occur after incubation for $3 \mathrm{~h}$ at $20{ }^{\circ} \mathrm{C}$ and that at $37^{\circ} \mathrm{C}$ it only 


\begin{tabular}{cc}
\hline Table 1: Equilibration Time of the Binding Process \\
\hline $\begin{array}{c}\text { incubation } \\
\text { temperature }\left({ }^{\circ} \mathrm{C}\right)\end{array}$ & $\begin{array}{c}\text { time at which equilibrium of } \\
\text { binding was reached (min) }\end{array}$ \\
\hline 4 & 600 \\
20 & 90 \\
37 & 20 \\
\hline
\end{tabular}

${ }^{a}$ Influenza virus was added to $5 \times 10^{6} \mathrm{MDCK}$ cells, at a concentration of $0.5,1$, or $5 \mu \mathrm{g}$ of viral protein $/ \mathrm{mL}$ in a final volume of $2 \mathrm{~mL}$ at $\mathrm{pH} 7.4$, and the mixtures were incubated at 4, 20, and 37 ${ }^{\circ} \mathrm{C}$. The extent of virus - cell binding was determined from fluorescence values in the pellet and supernatant, after addition of Triton X-100, following various times of incubation until no further increase in the extent of binding was observed. Experiments carried out at 20 and 37 ${ }^{\circ} \mathrm{C}$ were performed in the presence of inhibitors of endocytosis.

starts occurring after incubation for $40 \mathrm{~min}$. These results give us support to conclude that unspecific probe transfer of R18 does not occur during the incubation times used in our study.

To be able to determine all the kinetic parameters of the binding process (adhesion and detachment rate constants) as well as the type and number of binding sites, we determined the percentages of binding of influenza virus to MDCK cells at a fixed density using various concentrations of viral protein. Figure 1 represents Scatchard plots of the binding of influenza virus to MDCK cells at 4, 20, and 37 ${ }^{\circ} \mathrm{C}$. When Scatchard plots are drawn, two patterns may appear. If there is only one type of binding site for the ligand, that is, if the binding sites are identical but independent, a straight line is obtained. However, if there are two or more types of binding sites for the ligand, a smooth curve will result. The two or more types of binding sites may be nonidentical or may be identical but dependent. In this particular case, the plots shown in Figure 1 have a positive curvature. The fact that partial segments appear to be linear suggests the existence of two distinct types of binding sites for influenza virus on the surface of MDCK cells, similar to what has been described for liposomes interacting with cultured cells (24; see also Materials and Methods). To confirm our assumption, we have drawn plots of $r$ versus $L$ and we have obtained a continual hyperbolic curve for all three temperatures (data not shown), these results thus indicating that the binding is not cooperative; that is, the two types of binding sites are nonidentical. Consequently, this assumption was taken into account in all other calculations (see below). The percentages of binding of influenza virus to MDCK cells obtained at 4,20 , and $37{ }^{\circ} \mathrm{C}$ demonstrate that at the same temperature, higher virus concentrations yield lower percentages of binding (data not shown). This observation can be explained by the presence of a limited number of binding sites on the cell surface, which become saturated with an increase in the number of virus particles; i.e., at higher concentrations, the percentage of virus involved in effective binding becomes lower.

As described above, calculated values of viral binding (Figure 1) were determined by splitting the Scatchard plots obtained with the experimental values (Figure 1) into two segments, i.e., assuming two types of binding sites. This provided initial values for $k_{1}$ and $k_{2}$ (affinity constants for high- and low-affinity binding sites, respectively) and $N_{1}$ and $N_{2}$ (number of high- and low-affinity binding sites, respectively). Then refinements were obtained by choosing the best fits (Table 2). The initial time points of the kinetics of binding
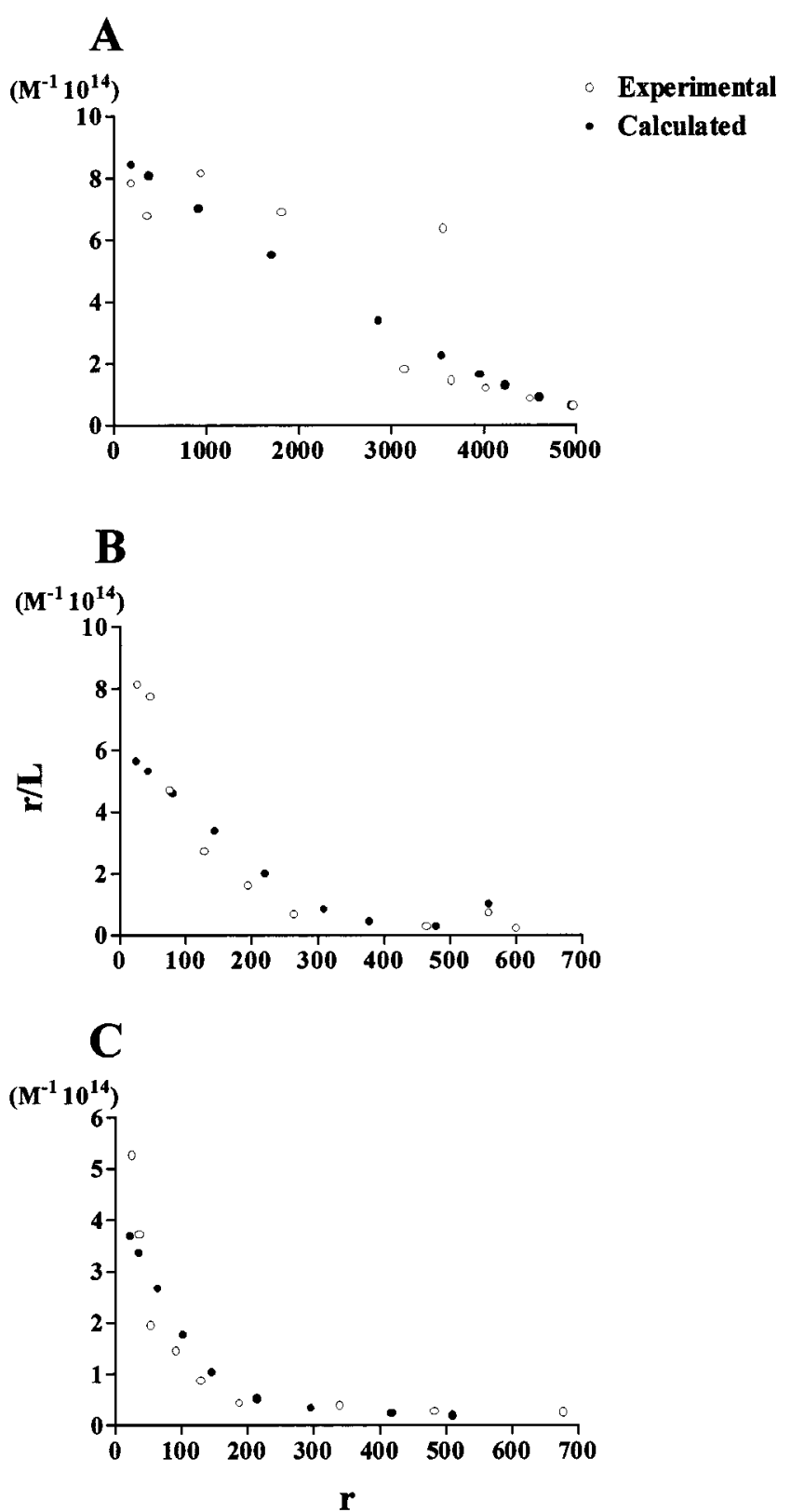

FIGURE 1: Scatchard plots of influenza virus binding to MDCK cells. The experimental values were calculated with the experimental percentages of influenza virus binding to MDCK cells. Influenza virus was added to $5 \times 10^{6} \mathrm{MDCK}$ cells, at various concentrations

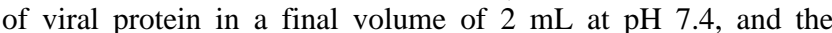
mixtures were incubated at 4 (A), 20 (B), and $37{ }^{\circ} \mathrm{C}$ (C). Experimental values for virus - cell binding were determined from fluorescence values in the pellet and supernatant, after addition of Triton X-100 to dequench the R18. Experiments carried out at 20 and $37{ }^{\circ} \mathrm{C}$ were performed in the presence of inhibitors of endocytosis. Calculated values were determined using the mass action kinetic model. All calculations were carried out assuming that $1 \mu \mathrm{g} / \mathrm{mL}$ influenza viral protein corresponds to the viral concentration of $2.043 \times 10^{-12} \mathrm{M}$. $r$ is the number of virus particles bound per cell; $L$ is the molar concentration of virus particles. See Materials and Methods.

provided the values of $c$. Parameters $D_{1}$ and $D_{2}$ (dissociation rate constants for both types of binding sites) were already fixed with the equations $D_{1}=c_{1} / k_{1}$ and $D_{2}=c_{2} / k_{2}$, where $c_{1}$ and $c_{2}$ represent the association rate constants, as described in Materials and Methods (Table 2). The calculations show that as the temperature increases the number of binding sites for influenza virus declines, especially the high-affinity 
Table 2: Kinetic Parameters for the Process of Binding of Influenza Virus to MDCK Cells ${ }^{a}$

\begin{tabular}{llll}
\hline \multirow{2}{*}{$\begin{array}{c}\text { kinetic } \\
\text { parameter }\end{array}$} & \multicolumn{3}{c}{ temperature } \\
\cline { 2 - 4 }$k_{1}\left(\mathrm{M}^{-1}\right)^{b} \mathrm{C}$ & \multicolumn{1}{c}{$20^{\circ} \mathrm{C}$} & \multicolumn{1}{c}{$37^{\circ} \mathrm{C}$} \\
$N_{1}{ }^{b}$ & $2 \times 10^{11}$ & $2 \times 10^{12}$ & $2.7 \times 10^{12}$ \\
$K_{1}\left(\mathrm{M}^{-1}\right)^{b}$ & 4300 & 300 & 150 \\
$c_{1}\left(\mathrm{M}^{-1} \mathrm{~s}^{-1}\right)^{b}$ & $2.6 \times 10^{14}$ & $6 \times 10^{14}$ & $4.05 \times 10^{14}$ \\
$D_{1}\left(\mathrm{~s}^{-1}\right)^{c}$ & $1.3 \times 10^{7}$ & $4.8 \times 10^{-4}$ & nd \\
$k_{2}\left(\mathrm{M}^{-1}\right)^{b}$ & $1.0 \times 10^{10}$ & 0.003 & nd \\
$N_{2}{ }^{b}$ & 2000 & $1.0 \times 10^{10}$ & $2 \times 10^{10}$ \\
$K_{2}\left(\mathrm{M}^{-1}\right)^{b}$ & $2 \times 10^{13}$ & $1.2 \times 10^{13}$ & $2 \times 10^{13}$ \\
$c_{2}\left(\mathrm{M}^{-1} \mathrm{~s}^{-1}\right)^{c}$ & $1 \times 10^{6}$ & $2.7 \times 10^{7}$ & nd \\
$D_{2}\left(\mathrm{~s}^{-1}\right)^{c}$ & $1 \times 10^{-4}$ & 0.003 & nd \\
\hline
\end{tabular}

${ }^{a} k_{1}$ is the affinity constant for high-affinity binding sites. $k_{2}$ is the affinity constant for low-affinity binding sites. $N_{1}$ is the number of highaffinity binding sites. $N_{2}$ is the number of low-affinity binding sites. $K_{1}$ is the binding association constant at equilibrium for high-affinity binding sites. $K_{2}$ is the binding association constant at equilibrium for low-affinity binding sites. $c_{1}$ is the association rate constant for highaffinity binding sites. $c_{2}$ is the association rate constant for low-affinity binding sites. $D_{1}$ is the dissociation rate constant for high-affinity binding sites. $D_{2}$ is the dissociation rate constant for low-affinity binding sites. ${ }^{b}$ Parameters fitted to data. ${ }^{c}$ Parameters calculated from fitted parameters. $c_{2}$ and $D_{2}$ are uncertain by about 1 order of magnitude, but their ratio should equal $k_{2}$.

binding sites, whereas the values of $k$ (affinity constant for a single virus with respect to the binding site) increase. Nevertheless, the binding association constant at equilibrium $K_{i}$, which is given by $K_{i}=N_{i} k_{i}$, declines as the temperature increases (Table 2). This indicates that for the same viral protein concentration, the fraction of virus bound declines with temperature increases, as can be deduced in Figure 1, which means that at equilibrium fewer virions associate with effective binding sites of the cells, when temperature increases.

The low-affinity binding sites also exhibit a relatively strong interaction with the virus, though about 20-100-fold weaker than that of the high-affinity binding sites. In this case, the changes with temperature are moderate within the range of uncertainty in their determination.

Following binding to the cells, influenza virus particles are internalized by receptor-mediated endocytosis. The equations describing total uptake of virus through binding and endocytosis are presented in Materials and Methods. When endocytosis occurs, the amount of total uptake of virions by the cells is modified in several respects. As shown in Table 3, the total uptake is larger as compared to what was obtained in the binding process (data not shown), at the same temperature. Moreover, the amount of virus associated with the cells increases for longer times than those in the absence of endocytosis, since cell association involves virus binding, internalization of the virus by endocytosis, and fusion of the virus with the endosomal membrane.

As described previously, we considered that there are two kinds of binding sites for influenza virus interacting with MDCK cells. However, we observed that for smaller values of total virus concentration, most of the contribution to binding and endocytosis came from the high-affinity binding sites. Thus, we also employed an approximation where only one type of "effective" receptor site was considered. We defined a quantity expressing a number of effective (highaffinity) binding sites $\left(N_{\text {eff }}\right)$ (Table 3$)$. The calculated values
Table 3: Experimental and Calculated Percentages of Influenza Virus Associated with MDCK Cells at $20{ }^{\circ} \mathrm{C}$ and the Corresponding Number of Effective Binding Sites ${ }^{a}$

\begin{tabular}{|c|c|c|c|c|}
\hline $\begin{array}{c}\text { viral } \\
\text { protein } \\
(\mu \mathrm{g})\end{array}$ & $\begin{array}{c}\exp \% \text { of } \\
\text { cell-associated } \\
\text { virus }( \pm \mathrm{SD})\end{array}$ & $\begin{array}{c}\text { calcd } \% \text { of } \\
\text { cell-associated } \\
\text { virus }\end{array}$ & $N_{\text {eff }}$ & $\begin{array}{c}\text { calcd } \% \text { of } \\
\text { cell-associated } \\
\text { virus (using } N_{\text {eff }} \text { ) }\end{array}$ \\
\hline 0.15 & $82.6 \pm 2.6$ & 80.9 & 380 & 81.8 \\
\hline 0.25 & $80.1 \pm 3.4$ & 80.3 & 380 & 81.3 \\
\hline 0.5 & $79.5 \pm 1.9$ & 78.8 & 380 & 80.0 \\
\hline 1 & $76.4 \pm 4.7$ & 75.2 & 380 & 76.9 \\
\hline 2 & $63.0 \pm 5.8$ & 66.4 & 380 & 68.7 \\
\hline 5 & $37.1 \pm 2.0$ & 43.3 & 380 & 43.5 \\
\hline 10 & $28.8 \pm 4.6$ & 27.2 & 450 & 28.8 \\
\hline 20 & $20.9 \pm 0.9$ & 17.1 & 600 & 18.1 \\
\hline 30 & $15.5 \pm 2.8$ & 13.3 & 700 & 15.9 \\
\hline
\end{tabular}

${ }^{a}$ The number of cells and the parameters $N, c$, and $D$ in these calculations were as described in Table 2 , at $20^{\circ} \mathrm{C}$. For the calculations (columns 3 and 5), we employed an $\epsilon$ of $2.6 \times 10^{-4} \mathrm{~s}^{-1}$. For the calculations in column 3 , we used two binding sites, whereas for those in column 5 , we used the parameters for the high-affinity binding except for their number which is given by $N_{\text {eff. }}$ The statistical tests of the calculations in column 3 gave for the root-mean-square error a value of 3.1, and the value of $r^{2}$ was 0.99. Influenza virus was added to $5 \times$ $10^{6}$ MDCK cells, at various viral protein concentrations in a final

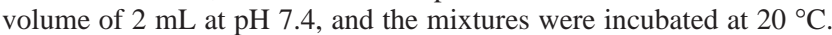
Experimental percentages of virus - cell association were determined from fluorescence values in the pellet and supernatant, after addition of Triton X-100, following incubation for $90 \mathrm{~min}$. Experimental values are given as the mean \pm standard deviation of three independent experiments performed in triplicate. Calculated values were determined using the mass action kinetic model.

Table 4: Kinetics of Virus Uptake by MDCK Cells at $20^{\circ} \mathrm{C}$ in the Presence and Absence of Inhibitors of Endocytosis ${ }^{a}$

\begin{tabular}{|c|c|c|c|c|c|}
\hline \multirow{4}{*}{$\begin{array}{l}\text { time } \\
(\mathrm{min})\end{array}$} & \multicolumn{5}{|c|}{$\%$ of virus uptake for $1 \mu \mathrm{g}$ of viral protein $/ \mathrm{mL}$} \\
\hline & \multirow{2}{*}{\multicolumn{2}{|c|}{$\begin{array}{l}\text { with inhibitors } \\
\text { of endocytosis }\end{array}$}} & \multicolumn{3}{|c|}{$\begin{array}{l}\text { without inhibitors } \\
\text { of endocytosis }\end{array}$} \\
\hline & & & \multirow[b]{2}{*}{$\exp$} & \multirow{2}{*}{$\begin{array}{l}\text { calcd (two } \\
\text { sites) }\end{array}$} & \multirow{2}{*}{$\begin{array}{c}\text { calcd (one site } \\
N_{\text {eff }}=380 \text { ) }\end{array}$} \\
\hline & $\exp$ & calcd & & & \\
\hline 15 & $36.8 \pm 3.6$ & 37.7 & $51.1 \pm 5.6$ & 48.2 & 53.5 \\
\hline 30 & $43.6 \pm 3.4$ & 37.8 & $60.6 \pm$ & 54 & 59.1 \\
\hline 60 & $39.6 \pm 3.5$ & 38.0 & $67.8 \pm 6.4$ & 66.4 & 68.7 \\
\hline
\end{tabular}

${ }^{a}$ The cell concentration was $4.1 \times 10^{-15} \mathrm{M}$; the virus concentration was $2.04 \times 10^{-11} \mathrm{M}$. The rate constant of endocytosis was $2.6 \times 10^{-4}$ $\mathrm{s}^{-1}$ for the calculations with two sites and $2 \times 10^{-4} \mathrm{~s}^{-1}$ for the calculations with one site. The other parameters are given in Table 2. Experimental percentages of virus - cell association were determined from fluorescence values in the pellet and supernatant, after addition of Triton X-100, following incubation. Experimental values are given as the mean \pm standard deviation of three independent experiments performed in triplicate. Calculated values were determined using the mass action kinetic model.

for the percentage of cell-associated virus, using $N_{\text {eff }}$, indicate that although there are two types of binding sites for influenza virus binding to MDCK cells, the high-affinity binding sites are the most important ones and so the influenza virus that binds to this type of binding sites plays the crucial role in the processes of binding and endocytosis.

Using our mass kinetic model, we determined that at 20 ${ }^{\circ} \mathrm{C}$, the rate constant of endocytosis, $\epsilon$, for influenza virus with this cell line is $2.6 \times 10^{-4} \mathrm{~s}^{-1}$. The kinetics of virus uptake by the cells is illustrated in Table 4 which gives experimental and calculated values in the presence and absence of inhibitors at $20^{\circ} \mathrm{C}$. The results demonstrate that most of the binding was reached within the first $15 \mathrm{~min}$, whereas total uptake due to endocytosis proceeds further. 


\begin{tabular}{|c|c|c|c|c|c|c|c|}
\hline & $\begin{array}{l}\text { [virus] in units of } \\
2.04 \times 10^{-12} \mathrm{M}\end{array}$ & $\begin{array}{l}\text { time } \\
(\mathrm{min})\end{array}$ & $\begin{array}{c}\text { rate constant of } \\
\text { endocytosis } \epsilon\left(\mathrm{s}^{-1}\right)\end{array}$ & $\begin{array}{l}\% \text { of the } \\
\text { total bound }\end{array}$ & $\begin{array}{c}\% \text { bound to } \\
\text { high-affinity sites }\end{array}$ & $\begin{array}{c}\% \text { bound to } \\
\text { low-affinity sites }\end{array}$ & $\%$ endocytosed \\
\hline binding & 1 & 1 & 0 & 23 & 22.4 & 0.6 & 0 \\
\hline \multirow{5}{*}{ (absence of endocytosis) } & 1 & 5 & 0 & 40.7 & 38.9 & 1.8 & 0 \\
\hline & 1 & 30 & 0 & 42.4 & 39.8 & 2.6 & 0 \\
\hline & 1 & 60 & 0 & 42.4 & 39.8 & 2.6 & 0 \\
\hline & 10 & 1 & 0 & 6.6 & 5.9 & 0.7 & 0 \\
\hline & 10 & 30 & 0 & 9.4 & 5.9 & 3.5 & 0 \\
\hline \multirow[t]{10}{*}{ endocytosis } & 1 & 1 & $2.6 \times 10^{-4}$ & 22.8 & 22.2 & 0.6 & 0.2 \\
\hline & 1 & 5 & $2.6 \times 10^{-4}$ & 39.5 & 37.8 & 1.7 & 2.4 \\
\hline & 1 & 30 & $2.6 \times 10^{-4}$ & 37.3 & 35.4 & 1.9 & 17.6 \\
\hline & 1 & 60 & $2.6 \times 10^{-4}$ & 32.5 & 31.0 & 1.5 & 34.0 \\
\hline & 10 & 1 & $2.6 \times 10^{-4}$ & 6.6 & 5.9 & 0.7 & 0.1 \\
\hline & 10 & 30 & $2.6 \times 10^{-4}$ & 9.0 & 5.9 & 3.1 & 4.0 \\
\hline & 10 & 60 & $2.6 \times 10^{-4}$ & 8.9 & 5.9 & 3.0 & 8.2 \\
\hline & 1 & 1 & 0.002 & 21.8 & 21.2 & 0.6 & 1.5 \\
\hline & 1 & 30 & 0.002 & 10.9 & 10.6 & 0.3 & 80.5 \\
\hline & 1 & 60 & 0.002 & 1.4 & 1.4 & 0.03 & 97.7 \\
\hline
\end{tabular}

${ }^{a}$ The parameters used in the calculations are given in Table 2.

Table 5 illustrates general features of the kinetics of cell association deduced by our model. We elaborate on these latter issues in the Discussion.

\section{DISCUSSION}

In this study, we have established experimental and theoretical procedures for quantitating the uptake of influenza virus by cells that exhibit endocytic capacity. The association constants for virus binding to the high-affinity sites of MDCK cells $\left(k_{1}\right.$, Table 2$)$ are very large in comparison with values obtained for Sendai virus adhesion to cells $(21,28)$ and severalfold larger than those reported for the binding of glycophorin liposomes to influenza hemagglutinin-expressing cells (29), although in this case the relative density of the viral protein is much lower than that in intact virions. Overall, these values are similar or larger than the values reported for the interaction of influenza virus with other cells (12, 18). Even the value of $k_{2}$ corresponding to binding to the low-affinity binding sites $\left(k_{2}=1-2 \times 10^{10} \mathrm{M}^{-1}\right)$ is relatively large. In comparison, the binding of PS/PC/Chol liposomes to high-affinity sites of $\mathrm{J} 774$ cells in suspension $\left(4{ }^{\circ} \mathrm{C}\right)$ is described by a $k$ of $3 \times 10^{9} \mathrm{M}^{-1}(24)$. At $20^{\circ} \mathrm{C}$, where our analysis has been more detailed, the deduced value of the dissociation rate constant, $D$, is in the same range as found for liposome-cell binding.

Hence, the large binding affinity of influenza virus may be attributed to the characteristics of its glycoproteins, namely, to the specific binding of the viral envelope hemagglutinin to target membrane sialic acid residues, a process that mediates infection in vivo $(1-3)$. An additional important element may be the fact that the viral surface has a spike structure. Such a structure implies a small radius of curvature of the surface forming a contact with the cellular membrane, which results in a small potential barrier for close approach (30), i.e., a large value of the forward rate constant of adhesion, $C$.

The fact that the fraction of virus bound to the cells in the absence of endocytosis decreases with elevation of temperature could be in a sense anticipated, since $D$ values increase with temperature more steeply than $C$ values. However, an unexpected pattern has emerged (Table 2); whereas the binding constant for the high-affinity sites increases with temperature by about 1 order of magnitude from 4 to $37^{\circ} \mathrm{C}$, there is a corresponding decrease in the number of highaffinity binding sites. It may be added that Figure 1 illustrates that at $4{ }^{\circ} \mathrm{C}$ the largest number of bound virions determined experimentally is 5000 , which is more than the largest number of calculated total binding sites at $20^{\circ} \mathrm{C}\left(N_{1}=300\right.$ and $N_{2}=1200$ ), or at $37{ }^{\circ} \mathrm{C}$. At 20 or $37^{\circ} \mathrm{C}$, the largest number of bound virions was found to be less than 700 (Figure 1). This result might indicate that as the temperature increases, the attached virus interacts with more sialic acidcontaining ligands on the cell surface, which results in effective enhancement in the binding strength and in fewer binding sites. An alternative speculation is that self-association of ligands is promoted at higher temperatures, due to an increase in their mobility and flexibility. Therefore, a highaffinity binding site for influenza virus on MDCK cells is a somewhat "fluid" entity, and not a permanent, and unchanged, location on the cell surface.

As we have pointed out, our analysis of binding and endocytosis has considered two types of binding sites. It is tempting to speculate that the high-affinity binding sites reflect sialic acid-containing ligands on MDCK cells, while the low-affinity binding sites would correspond to less specific, non-sialic acid-mediated, virus-cell interactions. The fact that the association constants for low-affinity binding sites remain virtually unchanged with temperature (Table 2) seems to support this notion. As would be expected, the extent of viral binding is greatly reduced, but it is not completely abolished, when target cells are incubated with neuraminidase beforehand, a treatment that removes sialic acid residues (3).

As pointed out, in Table 5 we illustrate general features of the kinetics of cell association deduced by the model. For clarity, we have normalized the viral concentration in 2.04 $\times 10^{-12} \mathrm{M}$ units, and considered two values, the higher concentration representing a 10 -fold increase with respect to the lower. The first six lines in Table 5 describe the kinetics of virus binding at $20{ }^{\circ} \mathrm{C}$ in the absence of endocytosis. The calculations show that equilibration in binding is achieved following incubation for $30 \mathrm{~min}$, and in fact, most of the binding terminates within $5 \mathrm{~min}$. In all cases, binding to the low-affinity sites begins before the high- 
affinity sites become saturated, but the extent is always low. For the lower virus concentration, the high-affinity binding sites bind 39- and 15-fold more virus particles than the lowaffinity sites at 1 and $30 \mathrm{~min}$, respectively. At the higher virus concentration, the corresponding ratios are smaller, 8.4 and 1.7, due to saturation of the high-affinity sites.

No time lag in the endocytosis process has been assumed, but its contribution to total cell association is insignificant for the first minutes. At $60 \mathrm{~min}$, half of the cell-associated virus has been endocytosed. The last three lines in Table 5 show that in the hypothetical case where $\epsilon=0.002 \mathrm{~s}^{-1}$, most of the added virus would be endocytosed within $30 \mathrm{~min}$. The calculated values $\left(\epsilon=2.6 \times 10^{-4} \mathrm{~s}^{-1}\right)$ illustrate that while endocytosis doubles the amount of virus associated with the cells, the amount endocytosed is partially at the expense of the amount of virus bound, which is less than the corresponding amount in the presence of inhibitors of endocytosis. With the lower virus concentration, the percent of virus bound reaches a maximum at about $5 \mathrm{~min}$.

It has been emphasized (20) that the binding step plays a crucial role in total particle uptake, even when eventually most of the uptake of particles is due to endocytosis. In the latter study, liposomes of two different compositions were characterized by the same rate constant of endocytosis, but their total uptake varied by 1 order of magnitude. In this context, it is interesting to note that influenza virus binds more avidly than Sendai virus to the same target cells, as noted by the respective association rate constants $(12,28$; see above). Since influenza virus penetrates its target cells by receptor-mediated endocytosis, a strong adhesion to the cells ensures that a large amount of virions will be available for internalization. In the case of Sendai virus, which fuses directly with the target cell plasma membrane at neutral $\mathrm{pH}$, this is less important, since, in theory, all bound virions are potentially infectious.

In this study, we assumed that the same rate of endocytosis applies for virus bound to either type of binding site. We do not have evidence to support this assumption, but at higher virus concentrations, ignoring endocytosis from the lowaffinity sites would result in underestimates for the percent of virus associated with the cells. This again stresses the importance of viral binding in the overall process of cell infection. Following viral attachment (to whatever type of binding site), there seems, therefore, to be little or no selectivity as to which bound virions will be internalized. This is emphasized by the fact that the rate constant of endocytosis for influenza virus is in the same range as the endocytosis rate constant of liposomes (24), which lack specific receptors on the cell surface.

The results and analysis developed in this study constitute an essential step toward being able to analyze the characteristics of fusion of virus with endosomes, which is the third stage in viral infection following binding and endocytosis.

\section{REFERENCES}

1. Bergelson, L. D., Bukrinskaya, A. G., Prokazova, N. V., Shaposhnikova, G. I., Kocharov, S. L., Shevchenko, V. P., Kornilaeva, G. V., and Fomina-Ageeva, E. V. (1982) Eur. J. Biochem. 128, 467-474.
2. Paulson, J. C., Rogers, G. N., Murayama, J. I., Sze, G., and Martin, E. (1986) in Virus Attachment and Entry into Cells (Crowell, R. L., and Lonberg-Holm, K., Eds.) pp 144-151, American Society for Microbiology, Washington, DC.

3. Pedroso de Lima, M. C., Ramalho-Santos, J., Flasher, D., Slepushkin, V. A., Nir, S., and Düzgünes, N. (1995) Biochim. Biophys. Acta 1236, 323-330.

4. Hernandez, L. D., Hoffman, L. R., Wolfsberg, T. G., and White, J. M. (1996) Annu. Rev. Cell Dev. Biol. 12, 627-661.

5. Hoekstra, D., and Pedroso de Lima, M. C. (1992) in Advances in membrane fluidity (volume 6) - Membrane interactions of HIV: Implications for pathogenesis and therapy in AIDS (Aloia, R. C., and Curtain, C. C., Eds.) pp 71-97, WileyLiss, New York.

6. Wiley, D. C., and Skehel, J. J. (1987) Annu. Rev. Biochem. 56, 675-697.

7. Mellman, I. (1996) Annu. Rev. Cell Dev. Biol. 12, 575-625.

8. Gaudin, Y., Ruigrok, R. W. H., and Brunner, J. (1995) J. Gen. Virol. 76, 1541-1556.

9. Ramalho-Santos, J., and Pedroso de Lima, M. C. (1998) Biochim. Biophys. Acta (in press).

10. Hoekstra, D., Klappe, K., de Boer, T., and Wilschut, J. (1985) Biochemistry 24, 4739-4745.

11. Pedroso de Lima, M. C., Nir, S., Flasher, D., Klappe, K., Hoekstra, D., and Düzgünes, N. (1991) Biochim. Biophys. Acta $1070,446-454$

12. Ramalho-Santos, J., Nir, S., Düzgünes, N., Pato de Carvalho, A., and Pedroso de Lima, M. C. (1993) Biochemistry 32, 2771-2779.

13. Ramalho-Santos, J., Pedroso de Lima, M. C., and Nir, S. (1996) J. Biol. Chem. 271, 23902-23906.

14. Rapaport, D., Nir, S., and Shai, Y. (1994) Biochemistry 33, 12615-12624.

15. Stegmann, T., Hoekstra, D., Scherphof, G., and Wilschut, J. (1986) J. Biol. Chem. 261, 10966-10969.

16. Bentz, J., Nir, S., and Covell, D. G. (1988) Biophys. J. 54, 449-462.

17. Dee, K. U., and Shuler, M. L. (1997) Biotechnol. Bioeng. 54, 468-490.

18. Düzgünes, N., Pedroso de Lima, M. C., Stamatatos, L., Flasher, D., Alford, D., Friend, D. S., and Nir, S. (1992) J. Gen. Virol. $73,27-37$

19. Larsen, C. E., Nir, S., Alford, D. R., Jennings, M., Lee, K.D., and Düzgünes, N. (1993) Biochim. Biophys. Acta 1147, 223-236.

20. Lee, K.-D., Nir, S., and Papahadjopoulos, D. (1993) Biochemistry 32, 889-899.

21. Nir, S., Klappe, K., and Hoekstra, D. (1986) Biochemistry 25, 2155-2161.

22. Nir, S., Klappe, K., and Hoekstra, D. (1986) Biochemistry 25, 8261-8266.

23. Nir, S., Stegmann, T., and Wilschut, J. (1986) Biochemistry 25, 257-266.

24. Nir, S., Peled, R., and Lee, K.-D. (1994) Colloids Surf. A 89, $45-57$

25. Matlin, K. S., Reggio, H., Helenius, A., and Simons, K. (1981) J. Cell. Biol. 91 (3, Part 1), 601-613.

26. Hoekstra, D., de Boer, T., Klappe, K., and Wilschut, J. (1984) Biochemistry 23, 5675-5681.

27. Sedmak, J. J., and Grossero, F. E. (1977) Anal. Biochem. 79 , 544-552.

28. Pedroso de Lima, M. C., Ramalho-Santos, J., Martins, M. F., Pato de Carvalho, A., Bairos, V., and Nir, S. (1992) Eur. J. Biochem. 205, 181-186.

29. Ellens, H., Bentz, J., Mason, J., Zhang, F., and White, J. (1990) Biochemistry 29, 9697-9707.

30. Nir, S., Bentz, J., Wilschut, J., and Düzgünes, N. (1983) Prog. Surf. Sci. 13, 1-124.

BI9812524 